\title{
Forecasting demand on the Ukrainian electricity market using socio-economic variables
}

\section{Mykhailo Krutsyak}

Faculty of Management and Marketing,

National Technical University of Ukraine "Igor Sikorsky Kyiv Polytechnic Institute"

37, Prosp. Peremohy, Kyiv, 03056 Ukraine

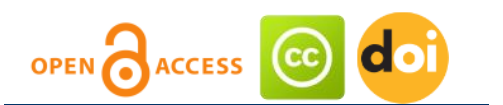

Article history:

Received: March 10, 2019

1st Revision: March 22,

2019

Accepted: April 12, 2019

\section{JEL classification: \\ C53 \\ F17 \\ L94 \\ Q41}

DOI:

10.14254/jems.2019.4-1.5

\begin{abstract}
This paper presents econometric methods and statistical datasets about changing socioeconomic factors and their influence on electricity demand (on the example of Ukraine) as the instrument for forecasting electricity demand. For this purpose, based on the results of well-known economists' works in the energy field, we selected linear multiple regression equations as the main method and changes in volumes of gross domestic product, the average price for electricity and the Ukrainian population (adapted to the situation in Ukraine due to the lack of reliable statistical data on part of the territory occupied by the Russian Federation for the period of 2013-2017) as the main factors. In the course of the study, the correlation between the exploring variable factors and the demand for electricity was found to be close (for the period 2000-2017). So, the given variables were used to construct linear regression equations for forecasting electricity demand in Ukraine (for the period up to 2035). As a result, it was possible to obtain the value of demand volumes, comparable to the volumes of demand provided by the profile ministries and agencies of Ukraine.
\end{abstract}

Keywords: electricity, market, demand, forecasting, socio-economic factors.

\section{Introduction}

The electricity market as a unique type of market operating on the principle of urgent demand supply in real time requires the forecasting of demand for electric energy, and the development of mathematical models, accordingly. First of all, such models should take into account the influence and development of factors that have an impact on the demand for electricity, then the ways and possibilities of its coverage, optimization (resources and generation), and much more. The accuracy of the modeling results largely depends on the economic situation of the

Corresponding author: Mykhailo Krutsyak

E-mail:m.krutsyak@gmail.com

This open access article is distributed under a Creative Commons Attribution (CC-BY) 4.0 license. 
industry and its entrants, as well as on the national economy and its energy and economic security. For this reason, the requirements for the adequacy of simulation results are more than rigid. However, because of the possibility of the onset of a stochastic events variety, meeting these requirements is becoming more and more difficult. The events in Ukraine that took place in recent years led to the changes in the electricity market situation. They include deployment of hostilities in the country, devaluation of the national currency, technological breakthroughs, consumer behavior changing, political course changing, global integration processes joining, market liberalization etc. For this reason, the economic-mathematical model to forecast an electricity demand taking into account a number of economic, social and demographic factors. If we omit them the prediction task becomes just a task of data extrapolation that is not connected with the development of objective reality within which the market of electricity is functioning.

\section{Literature review}

A number of scientists engaged in forecasting of electricity demand and investigating the adequacy of the results of such forecasting. Many research institutions, agencies, ministries, and private companies were interested in their research results. Among the most famous researches is the work of Egelioglu, Mohamad, and Guven (2001), where multiple linear regression equations are used and a mathematical model that took into account the influence of several economic factors on the change of electricity consumption in Northern Cyprus is constructed. As a result, there was established that the number of consumers, the electricity price and the number of tourists correlate with the change in electricity demand. With help of quantitative methods, some scientists (Fung \& Tummala, 1993; Harris \& Liu, 1993; Liu, Ang, \& Goh, 1991) in their researches described the possibility of assessing the impact of electricity prices as one of the decisive factors of energy saving on the part of consumers. Yan (1998) proved the link between electricity consumption and climate change in Hong Kong. Rajan and Jain (1999) supplemented the Yan (1998) model with the dependence between electricity demand changes and population changes. Fung and Tummala (1993) came to the conclusion that it is expedient to use the price of electricity, gross domestic product (GDP), trade balance and population to forecast the electricity demand in Hong Kong. Yau, Schneeweis, Robinson, and Weiss (2007) used indicators of GDP, electricity consumption, and population to forecast an electricity demand in Singapore. Lakhani and Bumb (1978) used electricity prices, average income per capita and expected long-term elasticity of electricity demand in Maryland. In some writings (Makridakis \& Wheelwright, 1989; Makridakis, Wheelwright, \& Hyndman, 2008) even more complicated economic-mathematical models, which include data sets of a diverse nature, are presented.

It is quite obvious that the larger the set of statistical data, the more adequate results of the simulation can be achieved, but it requires both their availability and the availability of necessary computational resources for their processing. In addition, there is an uncertainty: how many of all possible explanatory variables should be limited by the economic-mathematical model, since their growth brings zero effect to each of them?

Trying to forecast the electricity demand in New Zealand, Mohamed and Bodger (2005) proposed a logistic model based on the logistic growth curve. Using the model of logistic growth involves obtaining a level of electricity demand saturation with the help of Fibonacci searching technique. The estimated saturation level is used as a constant variable that corresponds to the optimal logistic growth curve, and the forecast is obtained by extrapolating a certain curve. The main advantage of using this approach is that it is possible to describe with sufficient precision the changes in the level of electricity demand in the historical retrospective. However, there is one significant drawback associated with constraints due to the level of saturation of the logistic growth curve (Bodger \& Tay, 1987; Sinclair Knight Merz, 2000).

Taking into account above information, it can be assumed that by using a model constructed and multiple linear regression equations that will include volumes of GDP, electricity prices and population, one can achieve the results of forecasting demand for electricity with a sufficiently high level of adequacy.

\section{Materials and Methods}

The proposed multi-factor multivariate linear regression model to forecast the electricity demand considering the dynamics of GDP, electricity prices and population is as follows:

$$
Y=a+b_{1} X_{1}+b_{2} X_{2}+b_{3} X_{3}+u
$$


where:

$Y$ - demand level or electricity consumption (GWh),

$X_{1}-$ GDP (millions UAH),

$X_{2}$ - electricity price (UAH per kWh),

$X_{3}$ - population (persons),

$u$ - standard error (so-called "white" noise).

In this case, each of the independent variables $X_{1}, X_{2}$ and $X_{3}$ is described by a simple linear regression equation reflecting the dynamics of these variables at time $t$ :

$$
X_{1}=c_{01}+c_{11} t, X_{2}=c_{02}+c_{12} t, X_{3}=c_{03}+c_{13} t
$$

where: equations.

$C_{01}, c_{11}, C_{02}, C_{12}, C_{03}$ i $C_{013}$ - the constants of the corresponding simple linear regression

Data about electricity consumption were obtained from the official web sites of The World Bank (n.d.), International Energy Agency (n.d.), State Enterprise National Energy Company UKRENERGO (n.d.), and the Ministry of Energy and Coal Industry of Ukraine (2017). Data about population changes in Ukraine and GDP were derived from the report of the State Statistics Service of Ukraine (n.d.) and CountyMeters information service (n.d.). Data about electricity prices were obtained from the official website of the National Regulatory (National Energy and Utilities Regulatory Commission [NEURC], n.d.). Given the reflection of electricity consumption in the structure of GDP, data of total electricity consumption are divided into two main groups: consumption by domestic (household) and non-domestic (non-household) consumers. Figure 1 shows the changes in consumption volumes and changes of explanatory variables for the period 2000-2017 years.

Figure 1 shows that due to the presence of noticeable nonlinearity in the electricity consumption (by domestic and non-domestic consumers and total over Ukraine), the population and GDP use of linear regression equations are considerably complicated. The first curve is characterized by the presence of a parabolic change in consumption with hogging in the middle (because of a significant reduction of energy supply in the ATO zone, the development of energy conservation technologies, reorientation of the national economy etc.). The second curve is characterized by the presence of a sharp fall (due to lack of data about a number of population that is in the ATO zone and annexed Crimea). And the third curve is characterized by the presence of a hyperbolic change (as a result of the accelerated devaluation of the hryvnia, etc.). That's why in the further study starting from the 2000 year data about population changing in Ukraine, GDP and electricity consumption will be presented without taking into account the share of people in the ATO zone and Crimea. In addition, volumes of GPD will be brought to constant prices of 2000 (using GDP deflator), taking into account the changes in the energy intensity of GDP. Adjusted data are as follows (Figure 2).

For testing the developed model, several different statistical tests were used. Among them are:

1) the adjusted determination coefficient $r^{2}$ to identify how well the model describes the actual consumption,

2) the $F$ test to validate the overall value of the model,

3 ) the $t$-test to validate the equality of the regression coefficients in the model.

In addition, the residuals (so-called "white" noise) $u$ were analyzed in order to test the model for autocorrelation.

For each of these variables, the dependence is represented by the corresponding correlation coefficients. The correlation matrix of the variables used in the regression analysis to simulate the electricity demand in Ukraine for the period from 2000 to 2017 is presented in Table 1.

All independent variables have a strong dependence with dependent variables (general consumption, as well as consumption by domestic and non-domestic consumers), and therefore significant in their use in the forecasting model. The correlation coefficient between GDP and population is 0.980 . However, in this case, the multicollinearity is observed. Makridakis et al. (2008) argue that multicollinearity in such cases can be easily eliminated by solving the task using OLS method. 
Figure 1: Dynamics of explanatory variables changes and changes in electricity demand, 2000-2017
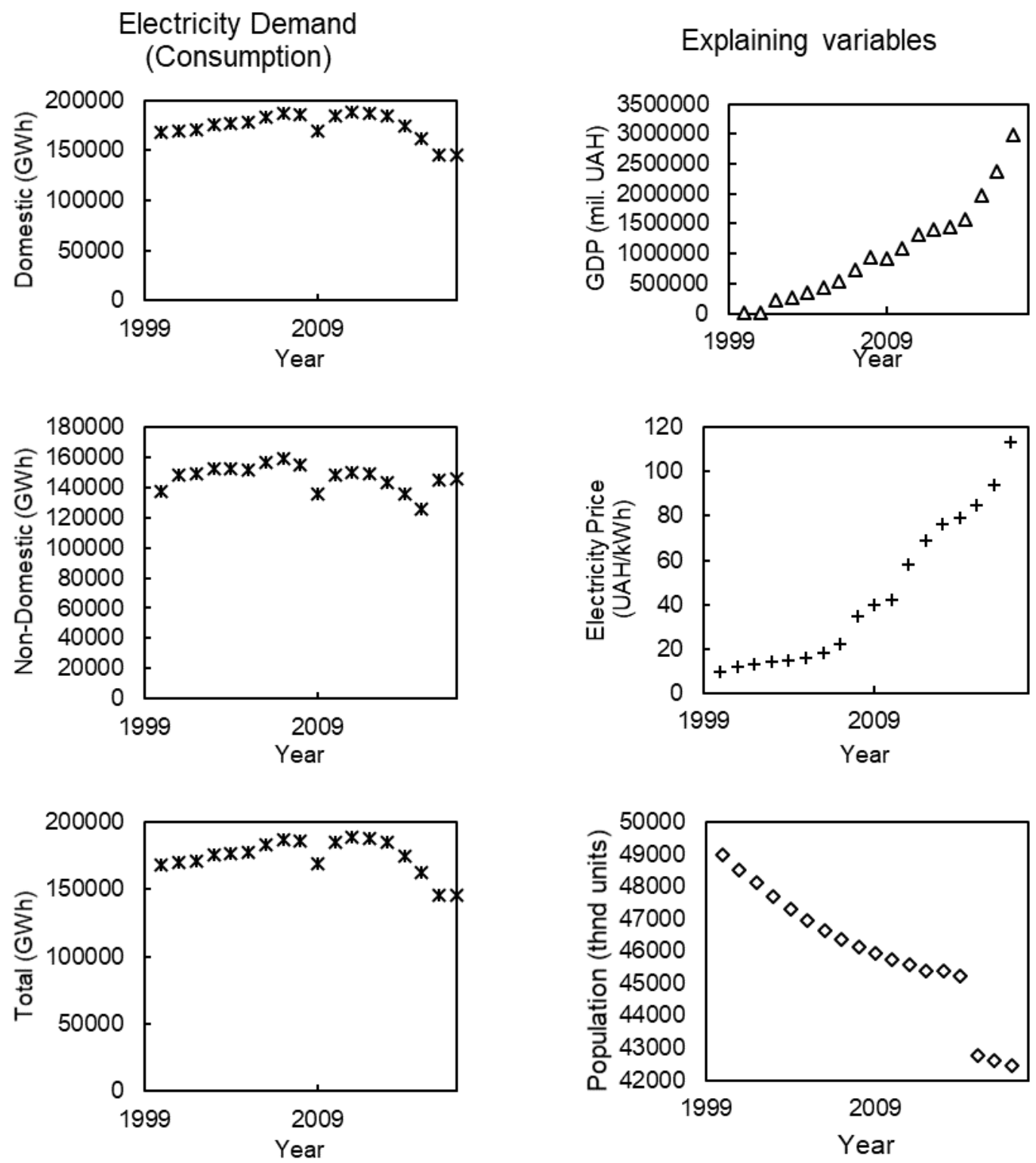

Source: "Electric power consumption", by The World Bank (n.d.). Available at https://data.worldbank.org/indicator/EG.USE.ELEC.KH.PC; "Statistics", by International Energy Agency (n.d.). Available at http://www.iea.org/statistics/statisticssearch; "Dispatch information", by State Enterprise National Energy Company UKRENERGO (n.d.). Available at https://ua.energy/diyalnist/dyspetcherska-informatsiya; "Statistics", by "State Statistics Service of Ukraine (n.d.). Available at http://www.ukrstat.gov.ua; "Tariffs on Electricity", by National Energy and Utilities Regulatory Commission (n.d.). Available at http://www.nerc.gov.ua/?id=19611/; "World population", by CountyMeters information service. (n.d.). Available at http://countrymeters.info/ 
Figure 2: Dynamics of the changed values of explanatory variables and electricity demand, 2000-2017
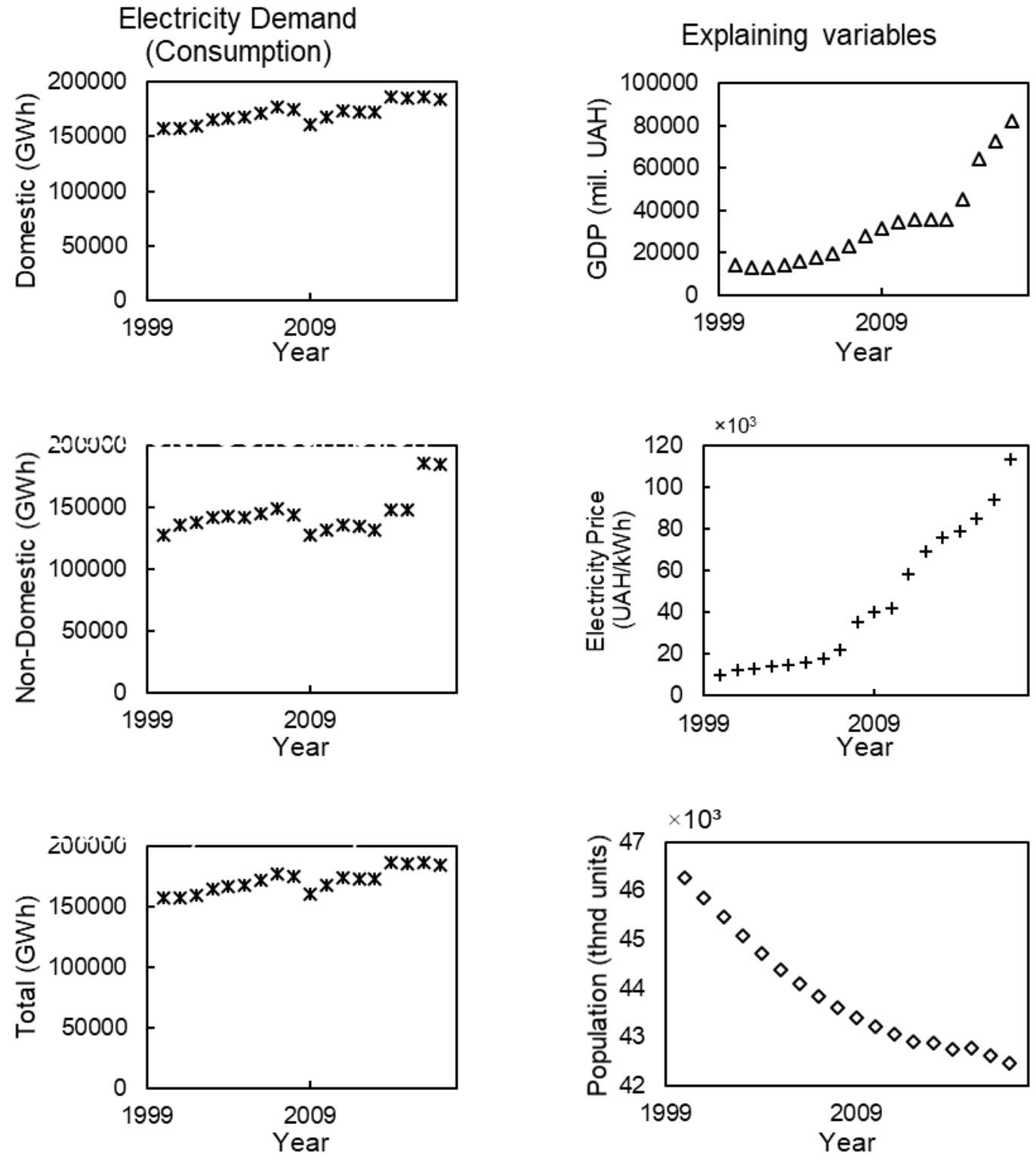

Source: author's calculations

\begin{tabular}{|c|c|c|c|c|c|c|}
\hline Variables & Domestic & Non-domestic & Total & GDP & Price & Population \\
\hline Domestic & 1 & & & 0.969 & 0.919 & 0.981 \\
\hline Non-domestic & & 1 & & 0.979 & 0.961 & 0.978 \\
\hline Total & & & 1 & 0.980 & 0.954 & 0.982 \\
\hline GDP & & & & 1 & 0.926 & 0.980 \\
\hline Price & & & & & 1 & 0.920 \\
\hline Population & & & & & & 1 \\
\hline
\end{tabular}

Source: author's calculations

The coefficients $a, b_{1}, b_{2}$ and $b_{3}$, Eq. (1), for each of the domestic and non-domestic groups and for total consumption are obtained by multiple linear regression using 17 years of data from 2000 to 2017 for each of variables. The resulting model is:

For domestic consumers:

$$
Y_{1}=1.32 \cdot 10^{5}+2.31 \cdot 10^{2} X_{1}-0.23 X_{2}-2.35 \cdot 10^{3} X_{3} \text {, }
$$


For non-domestic consumers:

$$
Y_{2}=2.75 \cdot 10^{5}-3.36 \cdot 10^{2} X_{1}+0.52 X_{2}-3.12 \cdot 10^{3} X_{3} \text {, }
$$

For total consumption:

$$
Y_{3}=4.07 \cdot 10^{5}+1.05 \cdot 10^{2} X_{1}+0.29 X_{2}-5.5 \cdot 10^{3} X_{3} \text {, }
$$

Each independent variable such as GDP $\left(X_{1}\right)$, electricity price $\left(X_{2}\right)$ and population $\left(X_{3}\right)$ is described using simple linear regression equations. The obtained regression equations for $X_{1}, X_{2}$ and $X_{3}$ have the following form:

$$
\begin{aligned}
& X_{1}=-7 \cdot 10^{6}+3588.8 \cdot 10^{3} t \\
& X_{2}=-12085+6.039 t \\
& X_{3}=474.47-0.214 t
\end{aligned}
$$

where $t$ - time (with one-year interval starting from 2000).

Table 2 shows the results of multiple linear regression testing model with the help of different statistical methods (adjusted $r^{2}$ determination coefficient, $F$-test and $t$-test with critical values of 99\%). The number of degrees of freedom for F-statistics is 3, for the determinant $r^{2}$ as well as for $t$-statistics is 32 .

\begin{tabular}{lccccccc}
\multicolumn{1}{l}{ Table 2: The testing results of the multiple linear regression model on a significance } \\
\hline Model & Adjusted $r 2$ & \multicolumn{2}{c}{$F$-test } & \multicolumn{4}{c}{$t$-test } \\
\cline { 3 - 9 } & & $99 \%$ critical $F$ & $F$ & $99 \%$ critical $t$ & $t 1$ & $t 2$ & $t 3$ \\
\hline Domestic & 0.87 & 4.44 & 256 & 2.72 & 4.02 & 3.17 & 29.8 \\
Non-domestic & 0.94 & 4.44 & 1075 & 2.72 & 17.2 & 21.4 & 20.9 \\
Total & 0.94 & 4.44 & 1022 & 2.72 & 10.0 & 17.6 & 30.2 \\
\hline
\end{tabular}

Source: author's calculations

Based on the results presented in Table 2, it becomes apparent that for the domestic consumer's model, the value of the determination coefficient $r^{2}$, which is equal to 0.87 , is quite significant. Usually, in such tasks, it is not more than 0.9. In the early 2000s, the electricity consumption by domestic consumers grew rapidly, primarily due to the accelerated transition of the population to electric heating, caused by an increase of prices for natural gas, and the widespread use of modern home appliances (video and telecommunications, washing machines, automatic machine, electric water heaters, dishwashers, electric cooking floors and cabinets, microwave ovens, etc.). However, at the end of the 2000s, under the influence of the global economic crisis and the increase of prices for electricity, consumption significantly decreased. The presence of such historical facts in the subsequent study, as can be seen from Table 2, led to a decrease in the determination coefficient $r^{2}$.

The adjusted determination coefficient for domestic and non-domestic consumers is significant. It means that in the case of domestic consumers, its consumption is at least $87 \%$ due to the changes in GDP, electricity prices and population. Accordingly, we can also explain the close relationship in the resulting model between the explanatory variables and overall consumption (including consumption by non-domestic consumers). The critical value of the F-test for each consumer group is much less than the calculated critical value $F$. Therefore, we can conclude that the simulation results obtained from the multiple linear regression equations (3) - (5) are sufficiently adequate (the adequacy of the simulation results is not less than $99 \%$ ). Similarly, $t$-test results: $t_{1}, t_{2}$, and $t_{3}$ for coefficients $X_{1}, X_{2}$ and $X_{3}$ are significantly larger than $99 \%$ of the critical value $t$. This means that the coefficients $b_{1}, b_{2}$ and $b_{3}$ in equations (3) - (5) are also significant.

Figure 3 shows the statistical values of actual electric energy consumption, as well as the values obtained using the developed model. As can be seen from these figures, the dynamics of the changes in the model value sufficiently repeats the form of the changes of actual retrospective data. 
Figure 3: The cross-check results of the proposed model
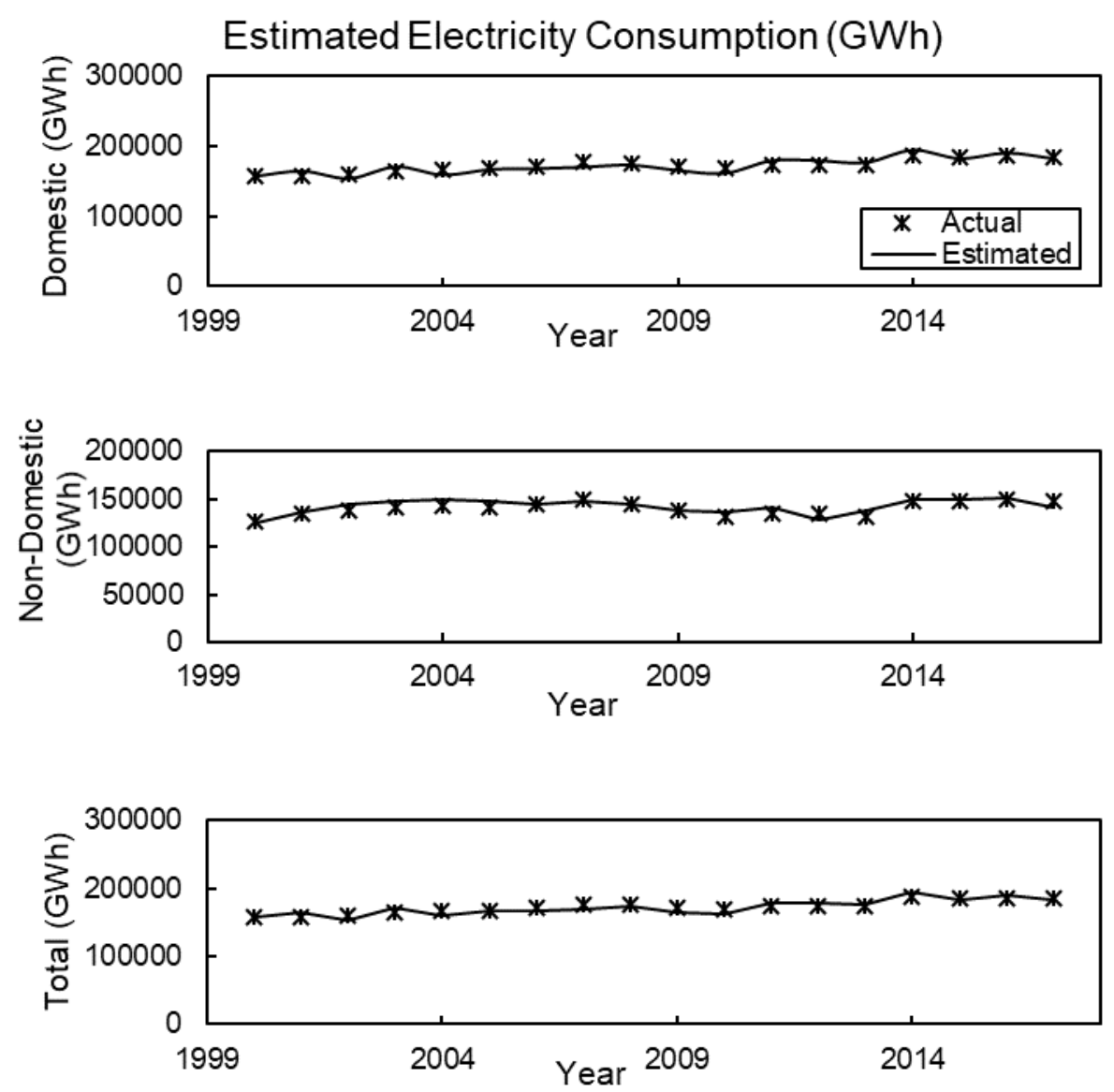

Source: author's calculations

Figure 4 depicts the residuals of multiple linear regression equations. The basic set of residuals is uniformly scattered over the entire plane and has no characteristic zone of high density. Thus, we can say that the distribution of estimated residuals has a stochastic distribution, and therefore no additional explanatory variables need to be entered. However, the connection between the residuals and the price of electricity still exists, but it is not significant and can be neglected based on the proof of Yau et al. (2007). According to Yau et al. (2007) proof, the residuals in case of domestic and non-domestic consumers and in case of total consumption are 19.22, 19.62 and 22.79, respectively, which do not exceed the critical value of $\chi^{2} 31.39$ (with an accepted probability of 0.05 ). It suggests that the autocorrelation of the residuals is negligible.

Figure 4: Residuals distribution of modeling and explanatory variables
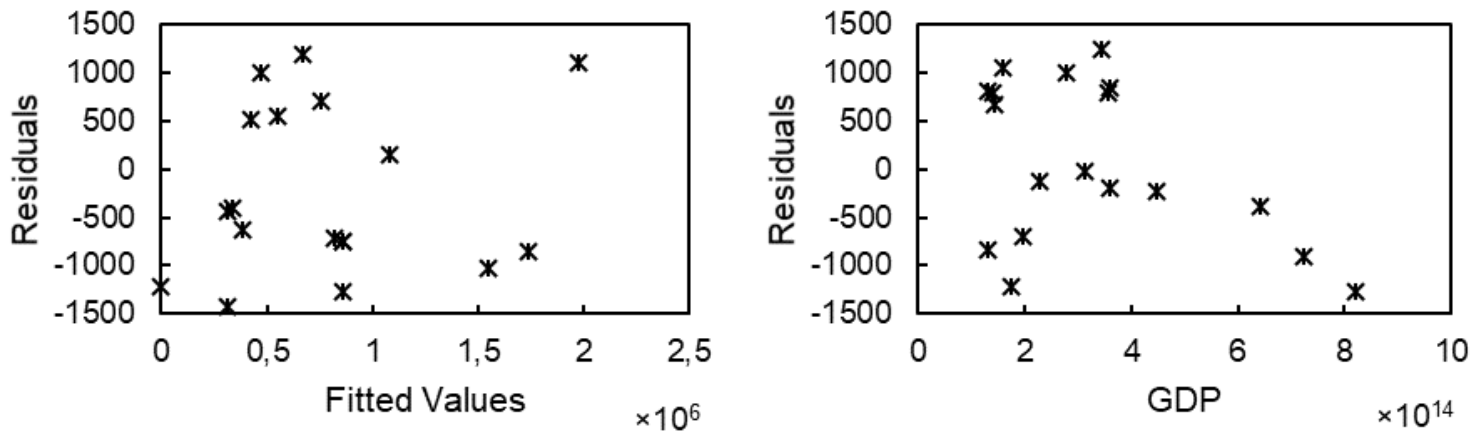

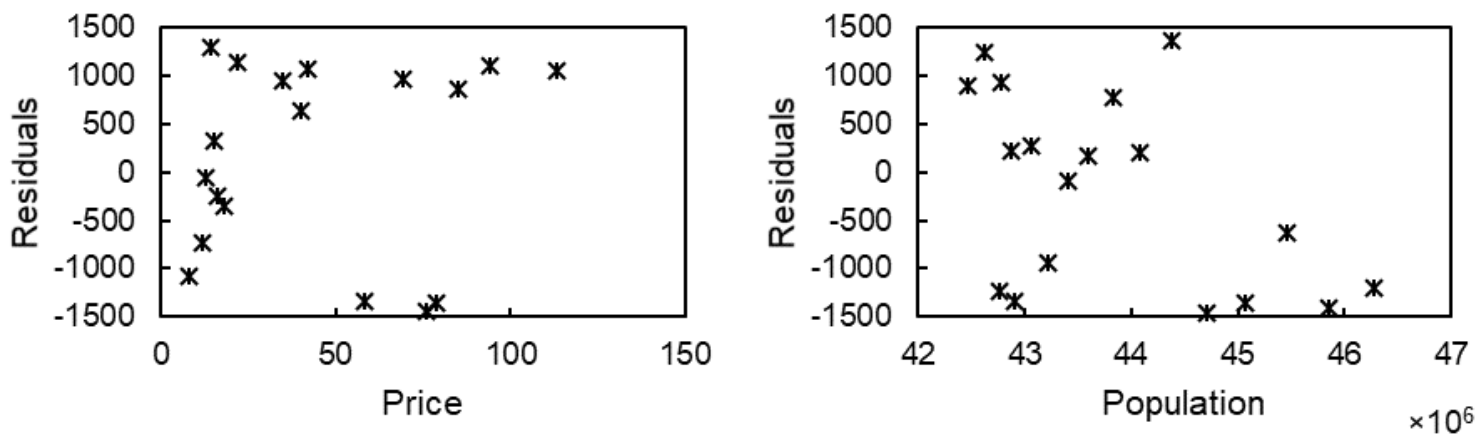

Source: author's calculations

In Figures 5-7 the forecasted values of electricity demand, obtained with the help of developed models for domestic and non-domestic consumers, as well as for the total consumption in Ukraine, are given.

Figure 5: Electricity demand forecasting electricity for domestic consumers (standard error $=3.2 \times 10^{3}$ )

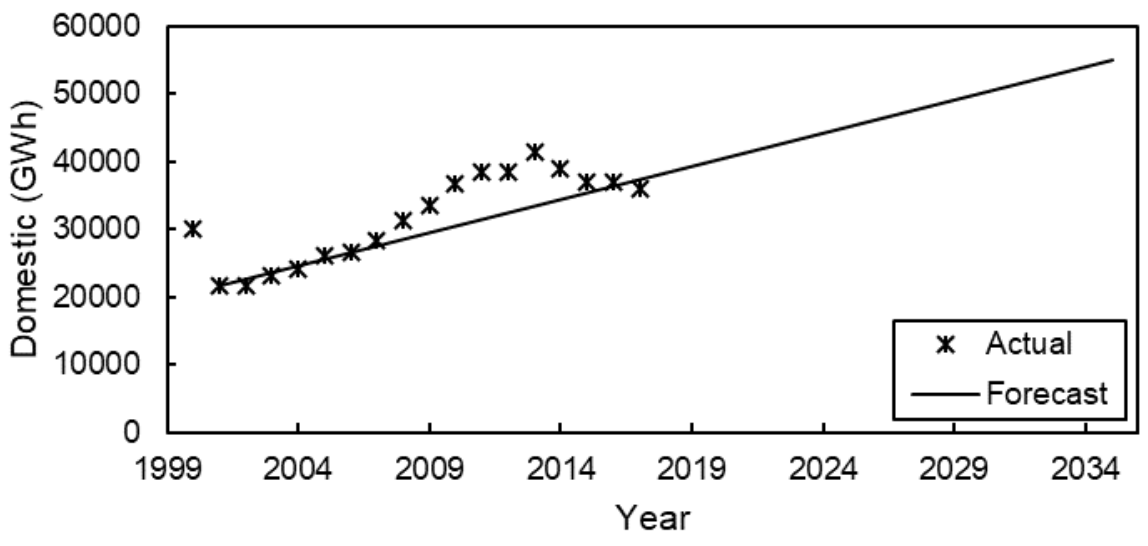

Source: author's calculations

Figure 6: Electricity demand forecasting electricity for non-domestic consumers (standard error $=5.8 \times 10^{3}$ )

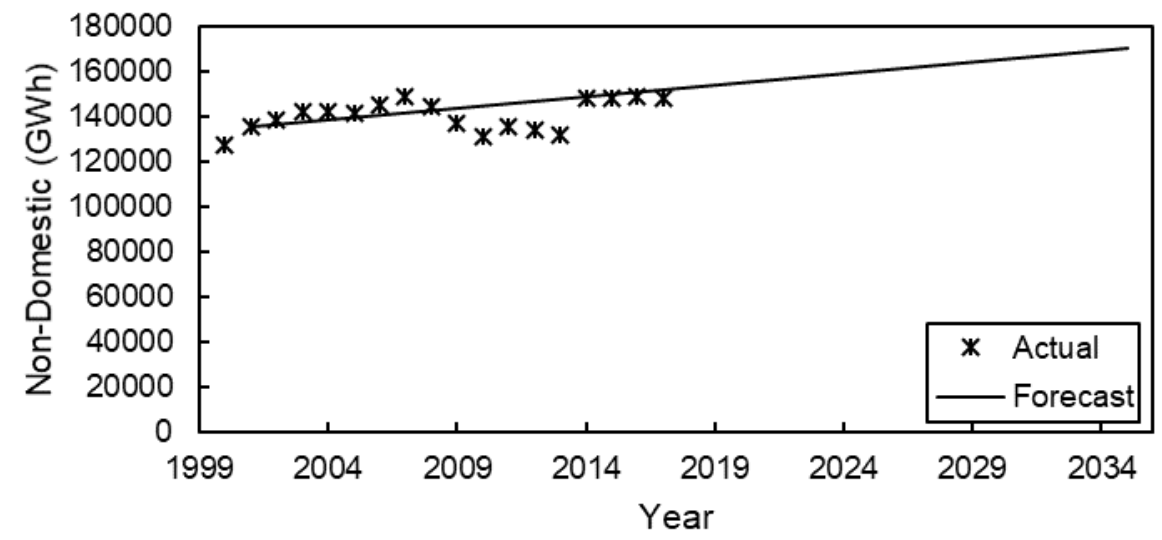

Source: author's calculations 
Figure 7: Electricity demand forecasting for total consumption in Ukraine (standard error = $4.1 \times 10^{3}$ )

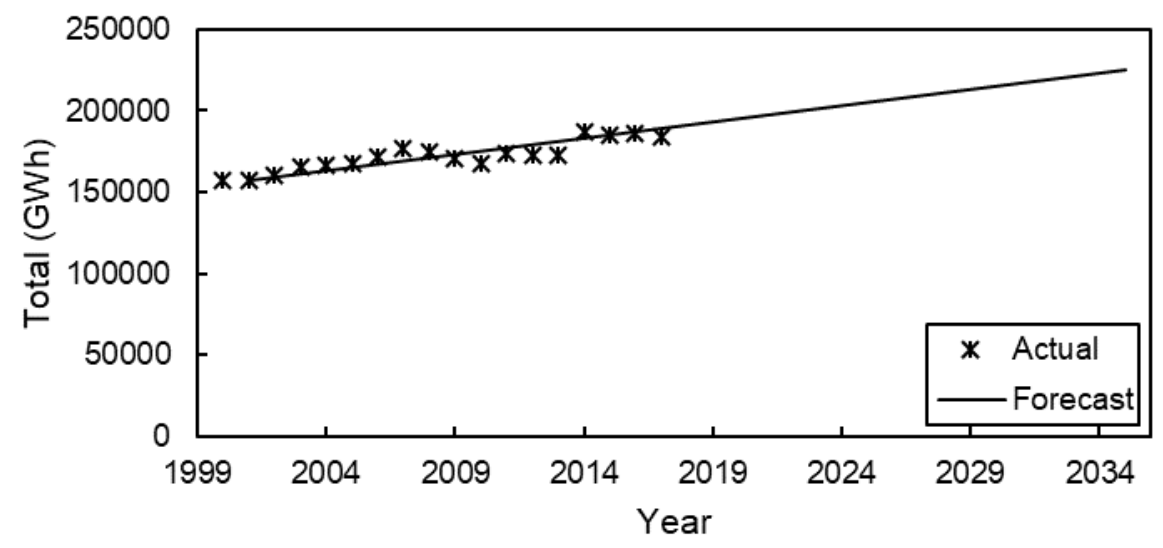

Source: author's calculations

\section{Results}

In Ukraine, national socio-economic forecasts are developed and published by the Ministry of Economic Development and Trade of Ukraine (2018), and at the regional level by regional state administrations. The relevant sector forecasts are prepared by the departments and ministries according to their profile. NEURC (n.d.) is delegated by the Ministry of Energy and Coal Industry of Ukraine (2017) to develop and publish its own forecasts for electricity demand based on an optimization model for energy supply and demand and taking into account the forecast of the socioeconomic development of Ukraine provided by the Ministry of Economic Development and Trade of Ukraine (2018). The latter is a descriptive model of market equilibrium in the energy sector.

The optimization model used by NEURC (n.d.) provides an opportunity to determine the state of equilibrium (balance) in the electricity market, according to the input power generating from different sources and the set of prices for electricity (in the wholesale and retail markets, as well as for domestic and non-residential consumers). Using optimization methods, the calculation of the balance continues until the balance of demand and supply. Forecasts of the NEURC (n.d.) are based on the assumption about the increase in consumption at annual rates of $1.2-2.0 \%$. In order to evaluate the suitability of the proposed model and compare the results, the model, developed by NEURC (n.d.), was chosen.

The predicted values obtained with the proposed model of multiple linear regression, the NEURC model, the model of Energy Strategy of Ukraine (New Energy Strategy of Ukraine until 2035 [MoESU], 2017) and the logistic model for domestic and non-domestic consumers, as well as in the case of total consumption are shown in Figures 8-10.

Figure 8: Comparison of forecasts for the group of domestic consumers

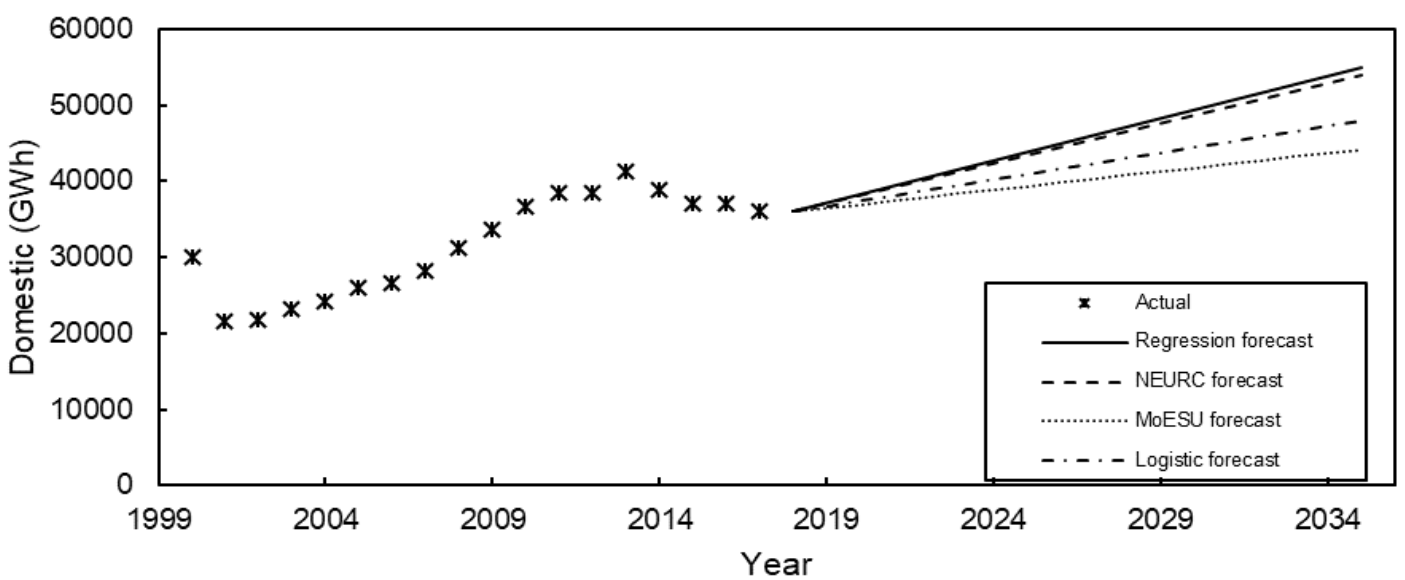

Source: "New Energy strategy of Ukraine until 2035", by Ministry of Energy and Coal Industry of Ukraine. (2017). Available http://mpe.kmu.gov.ua/minugol/doccatalog/document?id=245239554; "Perspectives of the 
development", by Ministry of Economic Development and Trade of Ukraine. (2018). Available at http://me.gov.ua/Documents/List?lang=uk-UA\&tag=Konsensus-prognoz.

Figure 9: Comparison of forecasts for the group of non-domestic consumers.

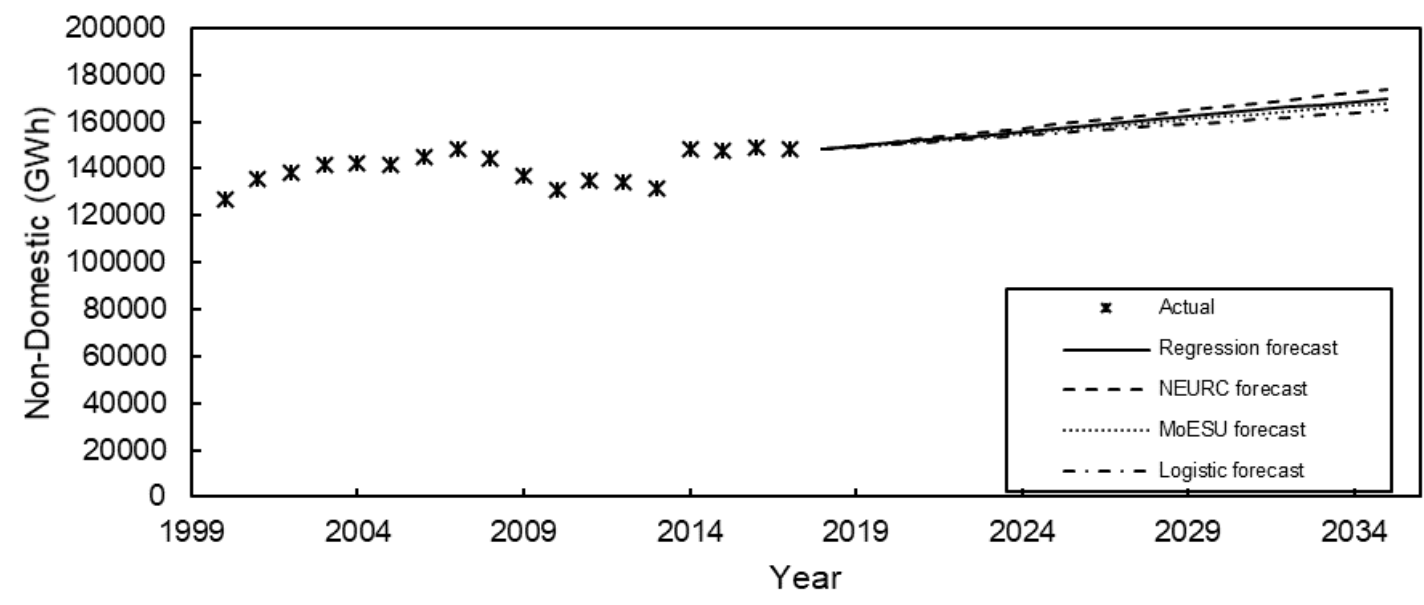

Source: "New Energy strategy of Ukraine until 2035", by Ministry of Energy and Coal Industry of Ukraine. (2017). Available http://mpe.kmu.gov.ua/minugol/doccatalog/document?id=245239554; "Perspectives of the development", by Ministry of Economic Development and Trade of Ukraine. (2018). Available at http://me.gov.ua/Documents/List?lang=uk-UA\&tag=Konsensus-prognoz.

Figure 10: Comparison of forecasts for the total demand in Ukraine

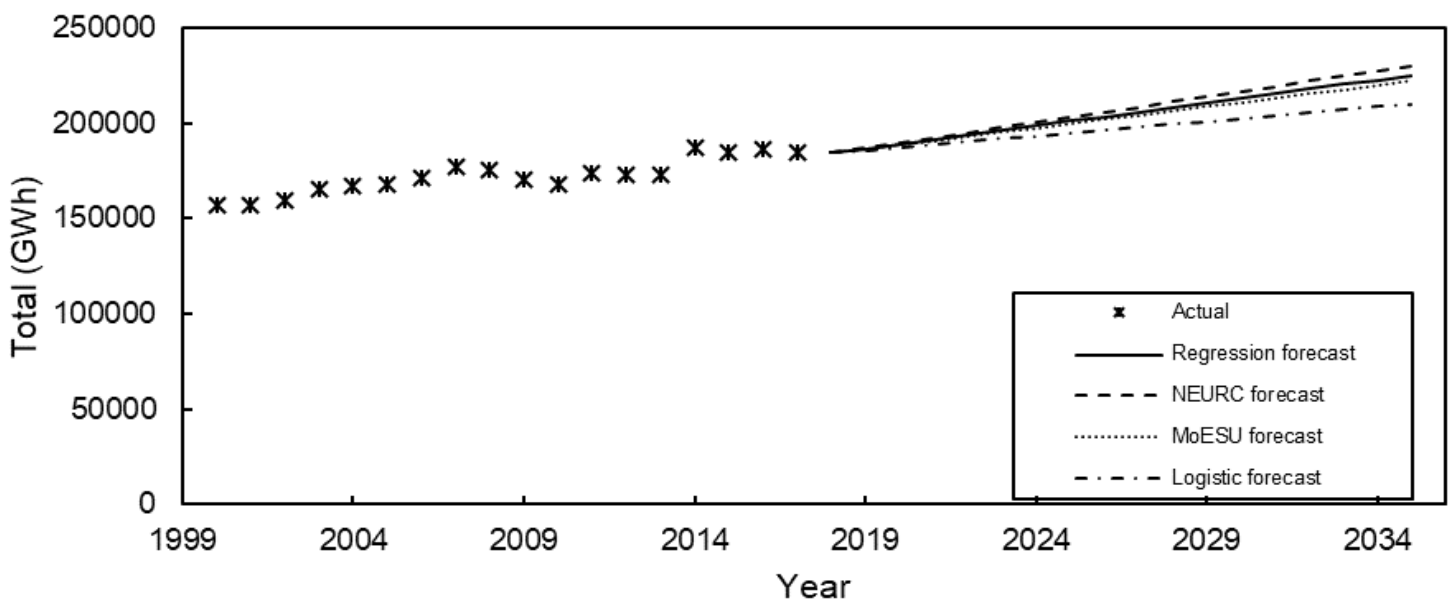

Source: author's calculations

Forecasts obtained using the model described by the multiple linear regression for the initial forecasting period are similar to the forecasts provided by the NEURC (n.d.). For the last period of forecasting, the results started to diverge slightly. The predicted values obtained with the help for the proposed model for non-residential consumers and, in case of total consumption in Ukraine, differ from the provided NEURC's predictive values on the larger side. In general, the forecasts obtained for these three models are very similar.

\section{Conclusions}

Summarizing the above, we distinguish the following:

1) An economic-mathematical model to forecast electricity demand based on a number of economic and social factors (both for domestic and non-domestic consumers and for Ukraine's consumers as a whole) using multiple linear regression equations is proposed;

2) The proposed models, during the statistical tests, have proved the high adequacy of the results obtained;

3) The results obtained using the proposed model were compared with the forecast data provided by NEURC; 
4) As a result of the comparison, it was found that the results obtained with the proposed model have sufficiently high accuracy, which to a large extent depends on the accuracy of predictions of the explanatory variables.

The direction of further research: in this paper, the simple linear regression equation was used for the simulation of explanatory variables. At present, the possibility of using other methods of forecasting these variables is explored.

\section{Appendix A. Supplementary material}

Supplementary data associated with this article can be found, in the online version, at https://doi.org/10.14254/jems.2019.4-1.5

\section{Funding}

The authors received no direct funding for this research.

\section{Citation information}

Krutsyak, M. (2019). Forecasting demand on the Ukrainian electricity market using socioeconomic variables. Economics, Management and Sustainability, 4(1), 46-57. doi:10.14254/jems.2019.4-1.5

\section{References}

Bodger, P. S., \& Tay, H. S. (1987). Logistic and energy substitution models for electricity forecasting: a comparison using New Zealand consumption data. Technological Forecasting and Social Change, 31(1), 27-48.

CountyMeters information service. (n.d.). World population. Retrieved from http://countrymeters.info.

Egelioglu, F., Mohamad, A. A., \& Guven, H. (2001). Economic variables and electricity consumption in Northern Cyprus. Energy, 26(4), 355-362.

Fung, Y. H., \& Tummala, V. R. (1993, December). Forecasting of electricity consumption: a comparative analysis of regression and artificial neural network models. In Advances in Power System Control, Operation and Management, 1993. APSCOM-93., 2nd International Conference on (pp. 782-787). IET.

Harris, J. L., \& Liu, L. M. (1993). Dynamic structural analysis and forecasting of residential electricity consumption. International Journal of Forecasting, 9(4), 437-455.

International Energy Agency. (n.d.). Statistics. Retrieved from http://www.iea.org/statistics/statisticssearch.

Lakhani, H. G., \& Bumb, B. (1978). Forecasting demand for electricity in Maryland: an econometric approach. Technological Forecasting and Social Change, 11(3), 237-259.

Liu, X. Q., Ang, B. W., \& Goh, T. N. (1991, November). Forecasting of electricity consumption: a comparison between an econometric model and a neural network model. In Neural Networks, 1991. 1991 IEEE International Joint Conference on (pp. 1254-1259). IEEE.

Makridakis, S., \& Wheelwright, S. C. (1989). Forecasting Methods for Management for the 21st Century. Simon and Schuster.

Makridakis, S., Wheelwright, S. C., \& Hyndman, R. J. (2008). Forecasting methods and applications. John Wiley \& Sons.

Ministry of Economic Development and Trade of Ukraine. (2018). Perspectives of the development. Consensus forecast. Retrieved from http://me.gov.ua/Documents/List?lang=ukUA\&tag=Konsensus-prognoz.

Ministry of Energy and Coal Industry of Ukraine. (2017). New Energy strategy of Ukraine until 2035. Retrieved from http://mpe.kmu.gov.ua/minugol/doccatalog/document?id=245239554.

Mohamed, Z., \& Bodger, P. (2005). Forecasting electricity consumption in New Zealand using economic and demographic variables. Energy, 30(10), 1833-1843.

National Energy and Utilities Regulatory Commission. (n.d.). Tariffs on Electricity. Retrieved from http://www.nerc.gov.ua/?id=19611. 
Rajan, M., Jain, V. K. (1999). Modelling of electrical energy consumption in Delhi. Energy, 24, 351-61.

Sinclair Knight Merz, CAE (Centre for Advanced Engineering, University of Canterbury, NZ) (2000). Electricity Supply and Demand to 2015, 5th ed. Christchurch: CAE University of Canterbury Campus.

State Enterprise National power company UKRENERGO. (n.d.). Dispatch information. Retrieved from https://ua.energy/diyalnist/dyspetcherska-informatsiya.

State Statistics Service of Ukraine (n.d.). Statistics. Retrieved from http://www.ukrstat.gov.ua.

The World Bank. (n.d.). Electric power consumption. Retrieved from https://data.worldbank.org/indicator/EG.USE.ELEC.KH.PC.

Yan, Y. Y. (1998). Climate and residential electricity consumption in Hong Kong. Energy, 23(1), 1720.

Yau, J. K., Schneeweis, T., Robinson, T. R., \& Weiss, L. R. (2007). Chapter 8: Alternative Investments Portfolio Management. CFA Institute Investment Books, 2007(4), 477-578.

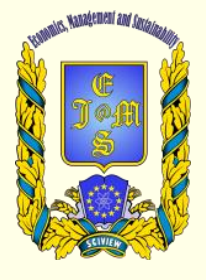

(c) 2016-2019, Economics, Management and Sustainability. All rights reserved. This open access article is distributed under a Creative Commons Attribution (CC-BY) 4.0 license. You are free to:

Share - copy and redistribute the material in any medium or format Adapt - remix, transform, and build upon the material for any purpose, even commercially.

The licensor cannot revoke these freedoms as long as you follow the license terms.

Under the following terms:

Attribution - You must give appropriate credit, provide a link to the license, and indicate if changes were made.

You may do so in any reasonable manner, but not in any way that suggests the licensor endorses you or your use.

No additional restrictions

You may not apply legal terms or technological measures that legally restrict others from doing anything the license permits.

Economics, Management and Sustainability (ISSN: 2520-6303) is published by Scientific Publishing House "CSR", Poland, EU and Scientific Publishing House "SciView", Poland

Publishing with JEMS ensures:

- Immediate, universal access to your article on publication

- High visibility and discoverability via the JEMS website

- Rapid publication

- Guaranteed legacy preservation of your article

- Discounts and waivers for authors in developing regions

Submit your manuscript to a JEMS at http://jems.sciview.net or submit.jems@sciview.net 